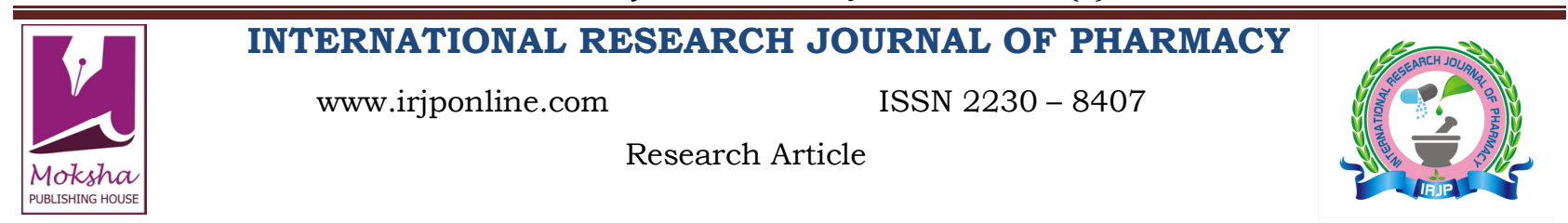

\title{
FIRST ORDER DERIVATIVE SPECTROPHOTOMETRIC METHOD FOR SIMULTANEOUS ESTIMATION OF TELMISARTAN AND CHLORTHALIDONE IN BULK AND PHARMACEUTICAL DOSAGE FORM
}

\author{
Parmar Kreny E.*, Mehta R. S.
}

Department of Quality Assurance, A. R. College of pharmacy and G. H. Patel institute of Pharmacy, Vallabh Vidyanagar, Anand, Gujarat, India

Email: kreny.25@gmail.com

Article Received on: 19/01/13 Revised on: 01/02/13 Approved for publication: 11/03/13

DOI: $10.7897 / 2230-8407.04348$

IRJP is an official publication of Moksha Publishing House. Website: www.mokshaph.com

(C) All rights reserved.

\section{ABSTRACT}

A simple, precise, and accurate method was developed for the estimation of Telmisartan (TEL) and Chlorthalidone (CHL) in bulk and pharmaceutical dosage form using first order derivative spectrophotometry. Wavelength selected for quantitation were $264.85 \mathrm{~nm}$ for Telmisartan (zero crossing point of Chlorthalidone) and $222.38 \mathrm{~nm}$ for Chlorthalidone(zero crossing point of Telmisartan). The method was validated with respect to linearity, accuracy, precision, limit of detection and limit of quantitation in accordance with the International Conference on Harmonisation (ICH) guidelines. Linearity was observed in concentration range of $8-48 \mu \mathrm{g} / \mathrm{ml}$ for Telmisartan and $2.5-15 \mu \mathrm{g} / \mathrm{ml}$ for Chlorthalidone. The limit of detection and limit of quantitation were found to be $0.234 \mu \mathrm{g} / \mathrm{ml}$ and $0.712 \mu \mathrm{g} / \mathrm{ml}$ for Telmisartan and $0.102 \mu \mathrm{g} / \mathrm{ml}$ and $0.309 \mu \mathrm{g} / \mathrm{ml}$ for Chlorthalidone. The percentage recovery of Telmisartan and Chlorthalidone was found to be $99.26 \%$ and $99.36 \%$ respectively. The $\%$ R.S.D. values for intra-day and inter-day precision study were $<1.0 \%$, confirming that the method was sufficiently precise. The method can be successfully employed for the simultaneous estimation of Telmisartan and Chlorthalidone in pharmaceutical formulations.

Keywords: Telmisartan, Chlorthalidone, Derivative spectrophotomtery, First order, Validation

\section{INTRODUCTION}

Telmisartan(TEL) is an Angiotensin II receptor antagonist used as an antihypertensive drug. Chemically it is $4^{\prime}-[[4-$ methyl-6-(1-methyl-2-benzimidazolyl)-2-propyl-1-

benzimidazolyl]methyl]-2-biphenylcarboxylic acid (Figure $1)^{1,2}$. Chlorthalidone(CHL) is diuretic drug used in treatment of hyperetension in combination with Telmisartan. CHL is chemically (RS)-2-chloro-5-(1-hydroxy-3oxoisoindolin-1-yl) benzenesulphonamide (Figure2) ) $^{1,2}$. TEL and CHL both are official in $\mathrm{IP}^{3}, \mathrm{BP}^{4}$ and USP ${ }^{5}$. TEL is estimated by Liquid Chromatography as per $\mathrm{IP}^{3}$ and Potentiometric titration as per $\mathrm{BP}^{4}$ and $\mathrm{USP}^{5}$. The analytical techniques reported for the determination of TEL include HPLC ${ }^{6-8}$, spectrophotometry ${ }^{9-}$ ${ }^{12}$, HPTLC $^{13,14}$ etc. either separately or in combination with other drugs.CHL is estimated by potentiometric titration as per $\mathrm{IP}^{3}$ and Liquid Chromatography as per $\mathrm{BP}^{4}$ and $\mathrm{USP}^{5}$. Several analytical method that use liquid chromatography ${ }^{15-}$ ${ }^{17}$, spectrophotometry ${ }^{19}$ have been reported in the literature for the determination of CHL in pharmaceutical preparation either separately or in combination with other drugs. Literature survey does not reveal any spectrophotometric method for simultaneous determination of TEL and CHL in Pharmaceutical dosage form. The present developed method is simple, precise and accurate for simultaneous determination of both drugs in their Pharmaceutical Dosage forms as per International Conference on Harmonization (ICH) guidelines ${ }^{20}$.

\section{MATERIALS AND METHOD Apparatus}

Instrument used was an UV-VIS-NIR Spectrometer Perkin Elmer Lambda 19 Range: $185-3200 \mathrm{~nm}$, with a pair of $1 \mathrm{~cm}$ matched quartz cells. Calibrated glass wares were used throughout the work.

\section{Reagents and chemicals}

Pure drug samples of TEL and CHL were obtained from Alembic Limited, Vadodara, Gujarat. Methanol AR Grade was used as solvent and obtained from Allied Chemical Corporation, Vadodara, Gujarat, India.

\section{Marketed formulation}

Combined tablet formulation Eritel- $\mathrm{CH} 40$ was procured from local market. Each tablet contains $40 \mathrm{mg}$ Telmisartan and $12.5 \mathrm{mg}$ Chlorthalidone.

\section{Preparation of standard stock solution}

Accurately weighed quantity of TEL $10 \mathrm{mg}$ and CHL $10 \mathrm{mg}$ was transferred into two separate $10 \mathrm{ml}$ volumetric flask, dissolved and diluted up to mark with methanol. This will give a stock solution having strength of $1000 \mu \mathrm{g} / \mathrm{ml}$.

\section{Preparation of working standard solution}

$5 \mathrm{ml}$ of standard stock solution of TEL $(1000 \mu \mathrm{g} / \mathrm{ml})$ and CHL $(1000 \mu \mathrm{g} / \mathrm{ml})$ was pipette out in to two separate $50 \mathrm{ml}$ volumetric flask and volume was adjusted to the mark with methanol to get $100 \mu \mathrm{g} / \mathrm{ml}$ of TEL and $100 \mu \mathrm{g} / \mathrm{ml}$ of CHL.

\section{Determination of wavelength for measurement}

$3.2 \mathrm{ml}$ of working standard solution of TEL $(100 \mu \mathrm{g} / \mathrm{ml})$ and $1.0 \mathrm{ml}$ of working standard solution of CHL $(100 \mu \mathrm{g} / \mathrm{ml})$ was pipette out in to $10 \mathrm{ml}$ volumetric flask and volume was adjusted to the mark with methanol to get $32 \mu \mathrm{g} / \mathrm{ml}$ of TEL and $10 \mu \mathrm{g} / \mathrm{ml}$ of CHL. Each solution was scanned between 200-400 nm.

The first order derivative spectra of each solution were obtained. The zero crossing points were found to be 222.38 $\mathrm{nm}$ and $264.85 \mathrm{~nm}$ for TEL and CHL respectively (figure 3). Wavelengths selected for quantification were $264.85 \mathrm{~nm}$ for TEL(zero crossing point for CHL) and $222.38 \mathrm{~nm}$ for CHL (zero crossing point for TEL). 
Preparation of calibration curve

Calibration curve for TEL

Standard TEL solutions of $8-48 \mu \mathrm{g} / \mathrm{ml}$ were prepared by pipetting out $0.8,1.6,2.4,3.2,4.0,4.8 \mathrm{ml}$ of the working standard solution of TEL $(100 \mu \mathrm{g} / \mathrm{ml})$ into series of $10 \mathrm{ml}$ volumetric flasks and the volume was adjusted to the mark. Absorbance of each solution was measured at $264.85 \mathrm{~nm}$ using First order derivative spectrophotometry. A calibration curve was prepared by plotting absorbance against respective concentration (Figure 4).

\section{Calibration curve for CHL}

Standard CHL solutions of $2.5-15 \mu \mathrm{g} / \mathrm{ml}$ were prepared by pipetting out $0.25,0.5,0.75,1,1.25$ and $1.5 \mathrm{ml}$ of the working standard solution of CHL $(100 \mu \mathrm{g} / \mathrm{ml})$ into series of $10 \mathrm{ml}$ volumetric flasks and the volume was adjusted to mark with methanol. Absorbance of each solution was measured at $222.38 \mathrm{~nm}$ using First order derivative spectrophotometry. A calibration curve was obtained by plotting absorbance against respective concentration (Figure 5).

\section{Development and validation of method Linearity and range}

Aliquots of working standard solutions of TEL and CHL were taken in $10 \mathrm{ml}$ volumetric flasks and diluted with methanol to get final concentrations in range of $8-48 \mu \mathrm{g} / \mathrm{ml}$ for TEL and of $2.5-15 \mu \mathrm{g} / \mathrm{ml}$ of CHL. This calibration range was prepared six times and absorbances were measured at respective wavelengths for each drug separately.

\section{Precision}

Precision of the method was determined by performing interday variation and intraday variation(\%RSD). Intra-day precision (\%RSD) was assessed by analyzing standard drug solutions within the calibration range, three times on the same day. Inter-day precision (\%RSD) was assessed by analyzing drug solutions within the calibration range on three different days over a period of 7 days.

\section{Repeatability}

For repeatability study, $32 \mu \mathrm{g} / \mathrm{ml}$ of TEL and $10 \mu \mathrm{g} / \mathrm{ml}$ concentration of $\mathrm{CHL}$ were measured six times.

\section{Recovery studies}

To study the accuracy of the proposed method, recovery studies were carried out by standard addition method at three different levels $(80 \%, 100 \%, 120 \%)$. A known amount of drug was added to pre analyzed sample powder and percentage recoveries were calculated.

\section{LOD and LOQ}

The LOD and LOQ were calculated by equation. Based on the standard deviation of the response and the slope, LOD and LOQ were estimated using the formulae:

$$
\begin{aligned}
& \mathrm{LOD}=3.3 \sigma / \mathrm{S} \\
& \mathrm{LOQ}=10 \sigma / \mathrm{S}
\end{aligned}
$$

Where, $\sigma=$ the standard deviation of the response, $S=$ the slope of the calibration curve

LOD and LOQ were determined from the standard deviations of the responses for six replicate determinations.

\section{Analysis of TEL and CHL in marketed Tablet} Formulation

To determine the content of TEL and CHL simultaneously in conventional tablets (Eritel- CH40 label claim $40 \mathrm{mg}$ TEL and $12.5 \mathrm{mg} \mathrm{CHL}$ ); twenty tablets were accurately weighed, average weight determined and ground to fine powder. A quantity of powder equivalent to $40 \mathrm{mg}$ TEL and $12.5 \mathrm{mg}$ CHL was transferred into $50 \mathrm{ml}$ volumetric flask containing $40 \mathrm{ml}$ methanol, sonicated for $20 \mathrm{~min}$ and diluted to mark with same solvent to obtain $800 \mu \mathrm{g} / \mathrm{ml}$ of TEL and $250 \mu \mathrm{g} / \mathrm{ml}$ of CHL. The resulting solution was filtered using $0.45 \mu \mathrm{m}$ filter (Millifilter, MA). $1 \mathrm{ml}$ of the above filtrate was diluted to $10 \mathrm{ml}$ with methanol to obtain $80 \mu \mathrm{g} / \mathrm{ml}$ of TEL and $25 \mu \mathrm{g} / \mathrm{ml}$ of CHL. $2 \mathrm{ml}$ of above solution was further diluted to $10 \mathrm{ml}$ with methanol to obtain $16 \mu \mathrm{g} / \mathrm{ml}$ of TEL and $5 \mu \mathrm{g} / \mathrm{ml}$ of CHL. The absorbance of the resulting solution was measured using first order derivative spectrophotometry at $264.85 \mathrm{~nm}$ for TEL and $222.38 \mathrm{~nm}$ for CHL. The concentration of each drug was calculated using equation of straight line.

Table 1: Result of Calibration readings for TEL

\begin{tabular}{|c|c|c|}
\hline $\begin{array}{c}\text { Concentration } \\
\mu \mathrm{g} / \mathrm{ml}\end{array}$ & $\begin{array}{c}\text { Absorbance Mean } \\
(\mathrm{n}=6) \pm \mathrm{SD}\end{array}$ & $\% \mathrm{RSD}$ \\
\hline 8 & $0.09622 \pm 0.00062$ & 0.651 \\
\hline 16 & $0.17271 \pm 0.00057$ & 0.329 \\
\hline 24 & $0.24907 \pm 0.00052$ & 0.212 \\
\hline 32 & $0.32141 \pm 0.00073$ & 0.227 \\
\hline 40 & $0.40121 \pm 0.00051$ & 0.128 \\
\hline 48 & $0.45348 \pm 0.00856$ & 0.188 \\
\hline
\end{tabular}

Table 2: Result of Calibration readings for CHL

\begin{tabular}{|c|c|c|}
\hline $\begin{array}{c}\text { Concentration } \\
\mu \mathrm{g} / \mathrm{ml}\end{array}$ & $\begin{array}{c}\text { Absorbance Mean } \\
(\mathrm{n}=6) \pm \mathrm{SD}\end{array}$ & \%RSD \\
\hline 2.5 & $0.06735 \pm 0.00057$ & 0.846 \\
\hline 5 & $0.13637 \pm 0.00082$ & 0.605 \\
\hline 7.5 & $0.19675 \pm 0.00064$ & 0.327 \\
\hline 10 & $0.24852 \pm 0.00104$ & 0.419 \\
\hline 12.5 & $0.31170 \pm 0.00061$ & 0.198 \\
\hline 15 & $0.37125 \pm 0.00072$ & 0.195 \\
\hline
\end{tabular}

Table 3: Statistical Data of TEL and CHL

\begin{tabular}{|c|c|c|}
\hline Parameters & Result for TEL & Result for CHL \\
\hline Linearity Range $(\mu \mathrm{g} / \mathrm{ml})$ & $8-48$ & $2.5-15$ \\
\hline Slope & 0.009 & 0.024 \\
\hline Intercept & 0.027 & 0.012 \\
\hline Limit of Detection $(\mu \mathrm{g} / \mathrm{ml})$ & 0.234 & 0.102 \\
\hline Limit of Quantitation $(\mu \mathrm{g} / \mathrm{ml})$ & 0.712 & 0.309 \\
\hline Regression Equation & $\mathrm{Y}=0.009 \mathrm{X}+0.027$ & $\mathrm{Y}=0.024 \mathrm{X}+0.012$ \\
\hline Co-Efficient of Determination $\left(\mathrm{r}^{2}\right)$ & 0.997 & 0.998 \\
\hline
\end{tabular}

Table 4: Intra-Day and Inter-Day study of TEL

\begin{tabular}{|c|c|c|c|c|c|}
\hline $\begin{array}{c}\text { Concentration } \\
(\mu \mathrm{g} / \mathrm{ml})\end{array}$ & $\begin{array}{c}\text { Intra-Day Abs. Mean } \\
(\mathrm{n}=3) \pm \mathrm{SD}\end{array}$ & \%RSD & $\begin{array}{c}\text { Concentrati-on } \\
(\mu \mathrm{g} / \mathrm{ml})\end{array}$ & $\begin{array}{c}\text { Inter-Day Abs. Mean } \\
(\mathrm{n}=3) \pm \mathrm{SD}\end{array}$ & $\%$ RSD \\
\hline 16 & $0.17212 \pm 0.0003$ & 0.214 & 16 & $0.17184 \pm 0.0002$ & 0.120 \\
\hline 24 & $0.24888 \pm 0.0003$ & 0.148 & 24 & $0.24872 \pm 0.0006$ & 0.276 \\
\hline 32 & $0.32147 \pm 0.0013$ & 0.43 & 32 & $0.32207 \pm 0.0004$ & 0.132 \\
\hline
\end{tabular}


Table 5: Intra-Day and Inter-Day study of CHL

\begin{tabular}{|c|c|c|c|c|c|}
\hline $\begin{array}{c}\text { Concentration } \\
\mu \mathrm{g} / \mathrm{ml}\end{array}$ & $\begin{array}{c}\text { Intra-Day Abs. Mean } \\
(\mathrm{n}=3) \pm \mathrm{SD}\end{array}$ & \%RSD & $\begin{array}{c}\text { Concentration } \\
\mu \mathrm{g} / \mathrm{ml}\end{array}$ & $\begin{array}{c}\text { Inter-Day Abs. Mean } \\
(\mathrm{n}=3) \pm \mathrm{SD}\end{array}$ & \%RSD \\
\hline 5 & $0.1371 \pm 0.0005$ & 0.408 & 5 & $0.13642 \pm 0.0006$ & 0.488 \\
\hline 7.5 & $0.19729 \pm 0.0006$ & 0.327 & 7.5 & $0.19625 \pm 0.0007$ & 0.383 \\
\hline 10 & $0.24837 \pm 0.0005$ & 0.229 & 10 & $0.24910 \pm 0.0004$ & 0.170 \\
\hline
\end{tabular}

Table 6: Repeatability study of TEL and CHL

\begin{tabular}{|c|c|c|}
\hline Concentration & TEL $(32 \mu \mathrm{g} / \mathrm{ml})$ & CHL $(10 \mu \mathrm{g} / \mathrm{ml})$ \\
\hline Absorbance & 0.32137 & 0.24869 \\
\hline & 0.32278 & 0.24746 \\
\hline & 0.32135 & 0.24821 \\
\hline & 0.32118 & 0.24989 \\
\hline & 0.32056 & 0.24738 \\
\hline & 0.32125 & 0.24952 \\
\hline Mean & 0.32141 & 0.24852 \\
\hline ISD & 0.00073 & 0.00104 \\
\hline \%RSD & 0.227 & 0.419 \\
\hline
\end{tabular}

Table 7: Determination of Accuracy

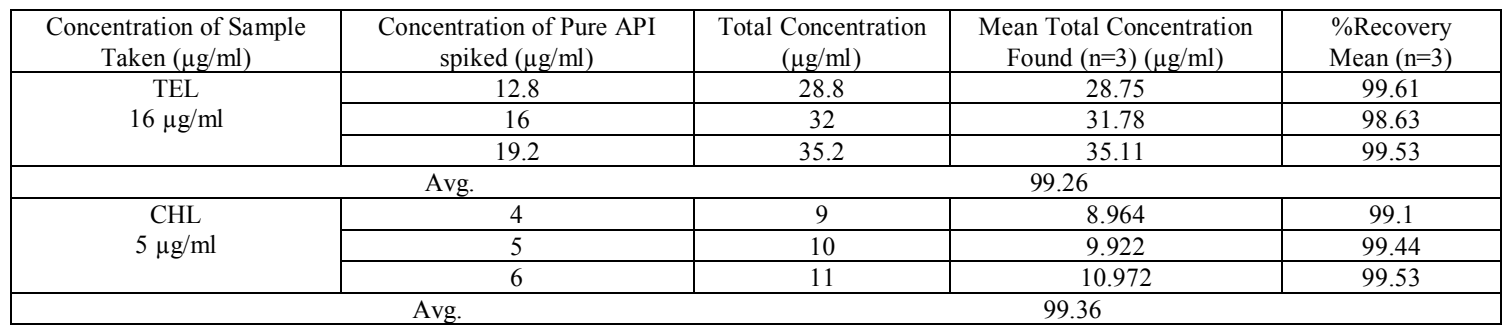

Table 8: Assay Result of Marketed Formulation

\begin{tabular}{|c|c|c|}
\hline Parameters & \multicolumn{2}{|c|}{ Eritel CH-40 TAB } \\
\hline & TEL & CHL \\
\hline Actual Concentration $(\mu \mathrm{g} / \mathrm{ml})$ & 16 & 5 \\
\hline Concentration Obtained $(\mu \mathrm{g} / \mathrm{ml})$ & 15.88 & 4.98 \\
\hline \%Purity & 99.3 & 99.73 \\
\hline \%RSD & 0.162 & 0.947 \\
\hline Limit $^{3}$ & $90-110$ & $92.5-$ \\
& & 107.5 \\
\hline
\end{tabular}<smiles>CCCc1nc2c(C)cc(-c3nc4ccccc4n3C)cc2n1Cc1ccc(-c2ccccc2C(=O)O)cc1</smiles>

Figure 1: Structure of Telmisartan (TEL)<smiles>NS(=O)(=O)c1cc(C2(O)NC(=O)c3ccccc32)ccc1Cl</smiles>

Figure 2: Structure of Chlorthalidone (CHL)

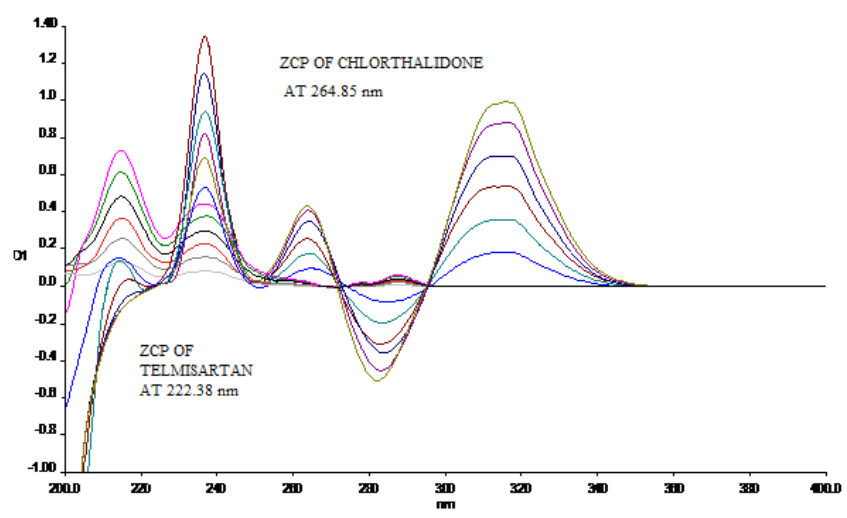

Figure 3: First order derivative overlay of TEL and CHL 


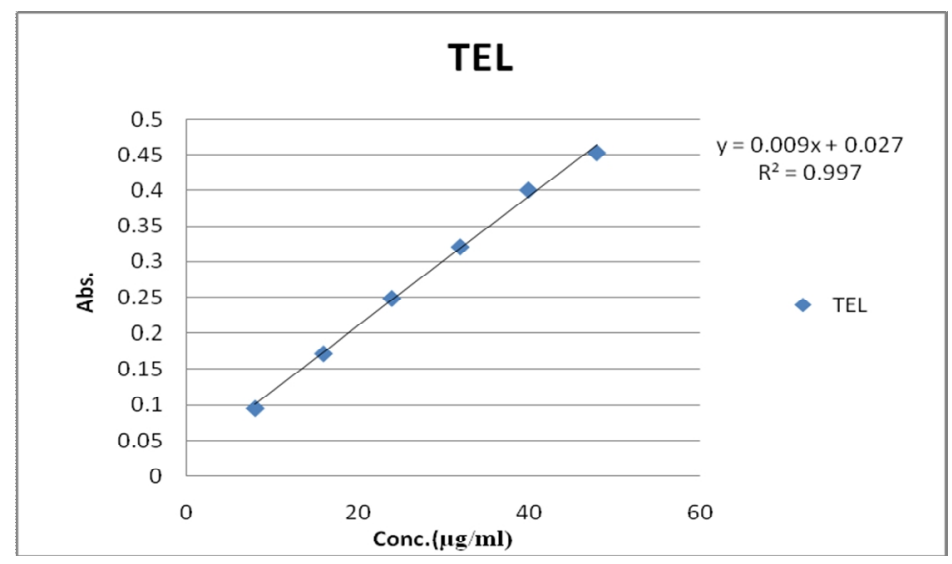

Figure 4: Calibration curve of TEL in Methanol

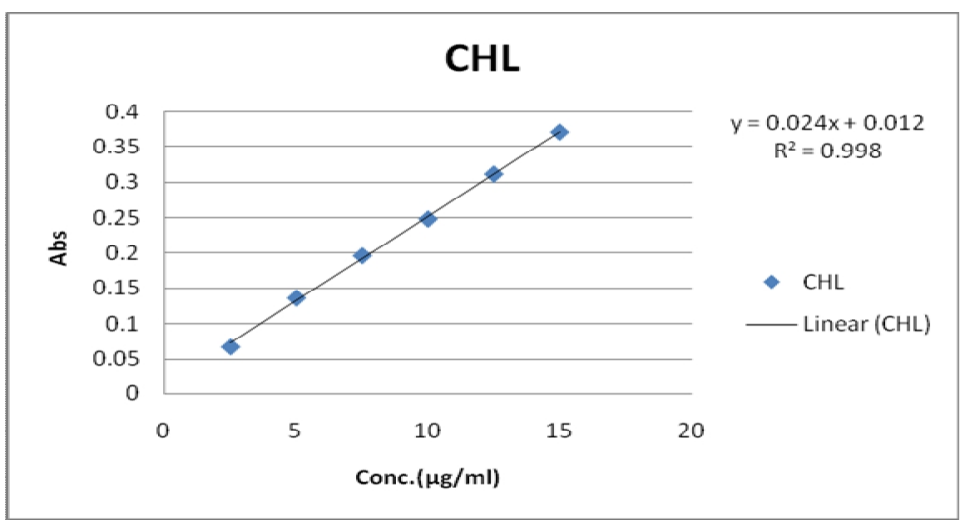

Figure 5: Calibration curve of CHL in Methanol

\section{RESULTS AND DISCUSSION \\ Validation}

Linearity

Linear regression data for the calibration plots revealed good linear relationships between absorbance and concentration over the ranges $8-48 \mu \mathrm{g} / \mathrm{ml}$ for TEL and $2.5-15 \mu \mathrm{g} / \mathrm{ml}$ for CHL. The linear equations for the calibration plots were $y$ $=0.009 \mathrm{x}+0.027$ and $\mathrm{y}=0.024 \mathrm{x}+0.012$ with Regression $\left(\mathrm{r}^{2}\right)$ being 0.997 and 0.998 for TEL and CHL, respectively (Figure 3,4,5) (Table 1, 2 and 3).

\section{Precision}

The precision of the method was expressed as relative standard deviation (RSD \%). The \%R.S.D. values for intraday precision study and inter-day study listed in (Table 4 and 5) were $<1.0 \%$, confirming that the method was sufficiently precise.

\section{Repeatability}

The \% RSD for absorbance values of TEL and CHL were found to be 0.227 and 0.419 respectively, as given in Table 6.

\section{Accuracy}

When the method was used for accuracy and subsequent analysis of both the drugs from the pharmaceutical dosage form, and spiked with 80,100 , and $120 \%$ of additional pure drug, the recovery was found to be $99.26 \%$ for TEL and $99.36 \%$ for CHL (Table 7 ).

\section{LOD and LOQ}

The LOD and LOQ were calculated by equation. The LOD and LOQ values were $0.234 \mu \mathrm{g} / \mathrm{ml}$ and $0.712 \mu \mathrm{g} / \mathrm{ml}$ for TEL and $0.102 \mu \mathrm{g} / \mathrm{ml}$ and $0.309 \mu \mathrm{g} / \mathrm{ml}$ for CHL.

\section{Analysis of TEL and CHL in marketed formulation}

When the Eritel $\mathrm{CH}-40$ tablets were analyzed, The \% purity was found to be $99.3 \%$ for TEL and $99.73 \%$ for CHL. (Table 8)

\section{CONCLUSION}

The proposed method was developed for the determination of TEL and CHL in the presence of each other. Methods was validated and found to be simple, rapid, sensitive, accurate and precise. The method was successfully used to estimate the amounts of TEL and CHL present in marketed tablet formulation containing TEL and CHL.

\section{ACKNOWLEDGEMENT}

Authors are thankful to Alembic Limited,Vadodara, Gujarat, India for providing gratis sample of Telmisartan \& Chlorthalidone.

\section{REFERENCES}

1. Maryadele J. O' Neil. The Merck Index. 14th ed. New Jersey: Merck Research Laboratories, Division of Merck and Co., Inc. Whitehouse station; 2006. 2193,9131.

2. Sean C Sweetman. MARTINDALE: The Complete Drug Reference. $36^{\text {th }}$ ed. Great Britain: Pharmaceutical Press; 2009. 1243,1409.

3. Indian Pharmacopoeia. Vol-II \& III. Ministry of Health \& Family Welfare. $6^{\text {th }}$ ed. Ghaziabad, India: Indian Pharmacopoeial commission; 2010.1076-77,2186-88.

4. British pharmacopoeia. Vol-I \& II. $6^{\text {th }}$ ed. London :The stationary office, 2010. 484-85, 2042-44. 
5. United States Pharmacopoeia-34 and National Formulary-29. Vol. II \& III. The United States Pharmacopoeial Convention, Rockville, MD, USA, 2011. 2321-22,4357-58.

6. Kumar GV, Murthy TEGK, Rao KRS. Validated rp-hplc method for the estimation of telmisartan in serum samples. International Journal Of Research In Pharmacy And Chemistry. 2011; 1(3) :703-706.

7. Sujana K, GowriSankar D, BalaSouri O, Swathi RG. Stability indicating rp hplc method for the determination of telmisartan in pure and pharmaceutical formulation. International Journal of Pharmacy and Pharmaceutical Sciences 2011; 3(2):164-167.

8. Jawla S, Jeyalakshmi K, Krishnamurthy T, Kumar Y. Development and Validation of Simultaneous HPLC method for Estimation of Telmisartan and Ramipril in Pharmaceutical Formulations. International Journal of PharmTech Research 2010; 2(2): 1625-1633.

9. Pandey A,Sawarkar H, Singh M,Kashyap P, Ghosh P.UVSpectrophotometric Method for estimation of Telmisartan in Bulk and Tablet Dosage Form. International Journal of ChemTech Research 2011;3(2): 657-660.

10. Tatane S. Development of UV Spectrophotometric Method of Telmisartan in Tablet Formulation. Journal of Advances in Pharmacy and Healthcare Research 2011;1:23-26.

11. Patel PB, Marolia BP, Shah SA, Shah DR. Second order derivative spectrophotometric method for simultaneous estimation of telmisartan and metoprolol in tablet dosage form. International Research Journal of Pharmacy 2012;3(5):259-62

12. Shah BB, Patel BB , Gohil KN , Patel PM. Difference Spectrophotometric Method Development and Validation For Simultaneous Estimation of Rosuvastatin Calcium and Telmisartan in Bulk and Combined Dosage Form. International Journal of Research in Pharmacy and Science 2012; 2(2): 106-114.

13. Patil UP, Gandhi SV, Sengar MR, Rajmane VS. A validated densitometric method for analysis of telmisartan and atorvastatin calcium in fixed dose combination. Journal Of The Chilean Chemical Society $\quad 2010 ; \quad 55(1): 94-96 . \quad$ http://dx.doi.org/10.4067/S0717. $\underline{97072010000100022}$
14. Deshpande P, Gandhi S, Bhavnani V, Pawar P. High performance thin layer chromatographic determination of Cilnidipin and Telmisartan in combined Tablet dosage form. International Research Journal Of Pharmacy 2012; 3(6) :219-222

15. Singh B, Patel DK, Ghosh SK. A reversed-phase high performance liquid chromatographic Method for determination of chlorthalidone in Pharmaceutical formulation. International Journal of Pharmacy and Pharmaceutical Sciences 2009;1(2):24-27.

16. Madhu Babu K, Bikshal Babu K. Reverse phase-hplc method development and validation for the Simultaneous estimation of Azilsartan medoxomil and Chlortalidone in pharmaceutical dosage forms. Journal of Atoms and Molecules 2012; 2(1): 117-126.

17. Elgawish M, Mustafa S. Simple and rapid HPLC method for simultaneous determination of Atenolol and Chlorthalidone in spiked human plasma. Soudi Pharmaceutical Journal 2011; 19(1):43-49. http://dx.doi.org/10.1016/j.jsps.2010.10.003

18. Mhaske RA, Sahasrabudhe S, Mhaske A.A Rp-hplc method for simultaneous determination of irbesartan, losartan, hydro-chlorothiazide and chlorthalidone-application to commercially available drug products. International Journal of Pharmaceutical Science and Research 2012 ;3(4):1116-1123.

19. Nivedita G, Akiful HM, Prashanth Kumar K, Pradeep Kumar T, Hasan Amrohi S, Diwan Prakash V et al. Simultaneous Estimation of Atenolol and Chlorthalidone as Bulk and In Tablet Dosage Form Using UvSpectrophotometry. Journal of Pharmacy and Biological Sciences 2012; $1(4): 20-23$.

20. ICH, Q2(R1) Validation of Analytical Procedure:Text and Methodology, International Conference on Harmonization, IFPMA, Geneva, Switzerland.[Cited 2013 Feb 5], Available from:www.ich.org/ fileadmin/Public.../ICH.../Q2_R1_Guideline.pdf

\section{Cite this article as:}

Parmar Kreny E., Mehta R. S.. First order derivative spectrophotometric method for simultaneous estimation of Telmisartan and Chlorthalidone in bulk and pharmaceutical dosage form. Int. Res. J. Pharm. 2013; 4(3):224-228 